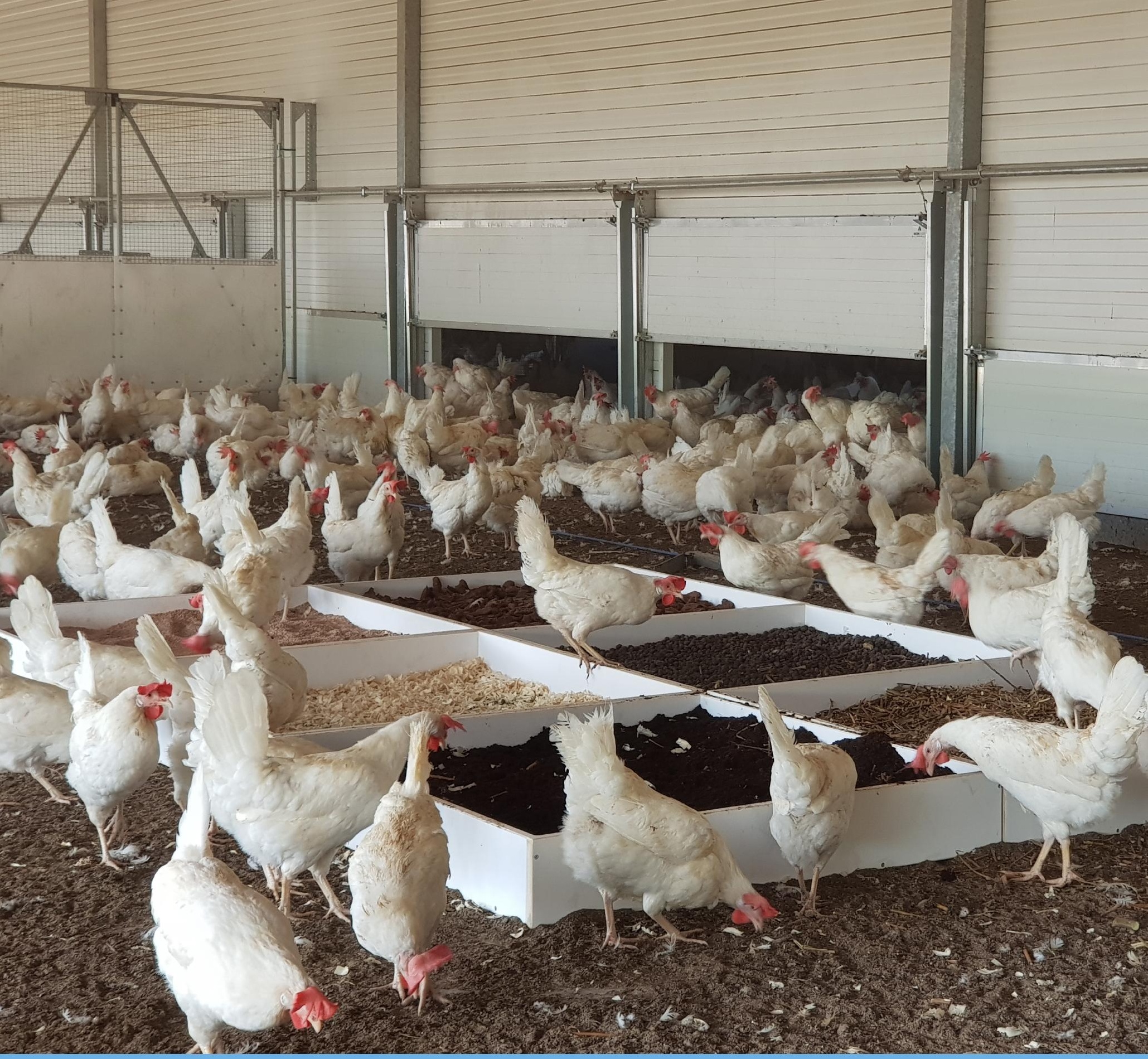

Substraat voorkeur voor foerageergedrag leghennen

Pilotstudie

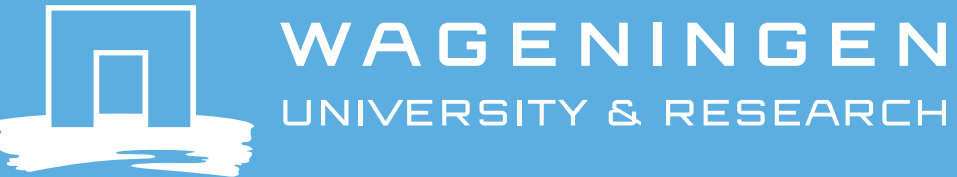





\section{Substraat voorkeur voor foerageergedrag leghennen}

Pilotstudie

Francesca Neijenhuis, Maudia van Wijhe-Kiezebrink, Ingrid de Jong

Wageningen Livestock Research

Dit onderzoek is uitgevoerd door Wageningen Livestock Research, in opdracht van en gefinancierd door de topsector Agri \& Food en Avined, binnen het project Gezondheid voor mens en dier door systeemverandering in de pluimveehouderij (MIP) (AF-16204)

Wageningen Livestock Research

Wageningen, september 2019

Rapport 1193 
Neijenhuis, F., M. van Wijhe-Kiezebrink, I. de Jong, 2019. Substraat voorkeur voor foerageergedrag leghennen: pilot studie; Wageningen Livestock Research, Rapport 1193.

Samenvatting In het project 'Gezondheid voor mens en dier door systeemverandering in de pluimveehouderij' wordt gewerkt aan alternatieven voor de huidige strooiselmest als scharrelsubstraat, waaruit de mest kan worden verwijderd om fijnstof- en ammoniakemissie te reduceren. In een pilot, uitgevoerd in drie weken op één commercieel leghennenbedrijf met een overdekte- en buitenuitloop, zijn 10 verschillende mogelijke scharrelsubstraten in steeds 6 bakken aangeboden. Uit deze pilot komt dat diatomeeënaarde, turf, schelpen en boekweitdoppen beter tegemoet komen aan de scharrelbehoefte van de leghennen dan houtkrullen, hydrokorrels, schors en lavasteentjes. Maar er was geen significant verschil in gebruik tussen diatomeeënaarde, turf, schelpen, gehakseld stro of boekweitdoppen onderling om in te foerageren.

Summary The project "Health for humans and animals through system change in poultry farming" is working on alternatives to the current litter as foraging substrate, from which manure can be removed to reduce particulate matter and ammonia emissions. In a pilot study, carried out during three weeks on one commercial laying hen farm with a wintergarden and outdoor range, 10 different possible foraging substrates were offered in 6 bins. This pilot shows that diatomaceous earth, peat, shells and buckwheat hulls meet the foraging requirements of laying hens better than wood shavings, hydro pellets, bark and lava stones. But there was no significant difference in use between diatomaceous earth, peat, shells, chopped straw, or buckwheat hulls for foraging.

Dit rapport is gratis te downloaden op https://doi.org/10.18174/499912 of op www.wur.nl/livestock-research (onder Wageningen Livestock Research publicaties).

(C) 2019 Wageningen Livestock Research

Postbus 338, 6700 AH Wageningen, T 03174839 53, E info.livestockresearch@wur.nl, www.wur.nl/livestock-research. Wageningen Livestock Research is onderdeel van Wageningen University \& Research.

Wageningen Livestock Research aanvaardt geen aansprakelijkheid voor eventuele schade voortvloeiend uit het gebruik van de resultaten van dit onderzoek of de toepassing van de adviezen.

Alle rechten voorbehouden. Niets uit deze uitgave mag worden vermenigvuldigd en/of openbaar gemaakt worden door middel van druk, fotokopie, microfilm of op welke wijze dan ook zonder voorafgaande toestemming van de uitgever of auteur.

Wageningen Livestock Research is NEN-EN-ISO 9001:2015 gecertificeerd.

Op al onze onderzoeksopdrachten zijn de Algemene Voorwaarden van de Animal Sciences Group van toepassing. Deze zijn gedeponeerd bij de Arrondissementsrechtbank Zwolle. 


\section{Inhoud}

$\begin{array}{ll}\text { Woord vooraf } & 5\end{array}$

$\begin{array}{ll}\text { Samenvatting } & 7\end{array}$

$\begin{array}{llr}1 & \text { Inleiding } & 9\end{array}$

$2 \quad$ Materiaal en methoden $r$

$\begin{array}{lll}2.1 & \text { Praktijkbedrijf } & 10\end{array}$

2.2 Scharrelsubstraten $\quad 11$

2.3 Bakken 14

2.4 Opzet pilot $\quad 14$

$\begin{array}{lll}2.5 & \text { Gedragswaarnemingen } & 17\end{array}$

$\begin{array}{ll}2.5 .1 \text { Ethogram } & 18\end{array}$

2.5.2 Beeldmateriaal verzamelen 18

$\begin{array}{ll}2.6 & \text { Analyse voorkeur hennen } \\ 2.7 & 19\end{array}$

$\begin{array}{lll}2.7 & \text { Beperkingen } & 19\end{array}$

3

$\begin{array}{ll}\text { Resultaten } & \mathbf{2 0}\end{array}$

3.1 Waarnemingen per substraat $\quad 20$

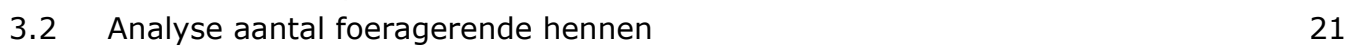

$4 \quad$ Discussie en conclusie $\quad 23$

$\begin{array}{ll}\text { Literatuur } & 24\end{array}$ 


\section{Woord vooraf}

Scharrelhouderij-systemen voor legkippen voorzien in belangrijke gedragsbehoeften van de dieren, met name het scharrelgedrag waar ze veel tijd per dag mee bezig zijn. Voor het welzijn van legkippen is de omslag van batterij-huisvesting naar scharrelsystemen dus gunstig geweest. Scharrelgedrag vereist echter een substraat (strooisel), en markteisen en regelgeving vereisen dat ook. In de huidige scharrelsystemen is dat substraat echter het grootste deel van de tijd de gedroogde en uiteengevallen mest van de dieren zelf. Niet voor niks is de Engelse vakterm voor strooisel 'litter', wat vrijwel synoniem is aan rommel of stalmest. Ook in de Nederlandse pluimveepraktijk is strooisel in feite synoniem met mest.

Gedroogde mest is echter ook een grote bron van fijnstof, die in de stallucht terecht komt door het scharrelgedrag van de dieren. De luchtkwaliteit in legpluimveestallen is daarom ongezond voor mens en dier. Via het ventilatiesysteem wordt dit fijnstof vervolgens naar buiten geblazen, wat lokale gezondheidsrisico's voor omwonenden oplevert.

Eén van de manieren om dit probleem aan te pakken is aangrijpen bij de bron, door legkippen niet meer in hun eigen mest te laten scharrelen, maar in een ander substraat. Zo'n substraat zou het mogelijk moeten maken om mest frequent uit dat strooisel te verwijderen, zodat het geen bron van fijnstof meer kan zijn.

We weten echter niet zo precies aan welke eisen een scharrelsubstraat moet voldoen, om geschikt en aantrekkelijk te zijn voor leghennen. In de wetenschappelijke literatuur is er verrassend weinig over bekend. En die kennis is wél nodig voor een goed ontwerp van een scharrelgebied waarin mest frequent verwijderd kan worden.

Dit rapport doet verslag van een eerste pilotstudie om die leemte in onze kennis op te vullen. De studie kon noodgedwongen alleen indicatief zijn, maar levert voldoende inzichten op om verder ontwerpwerk mogelijk te maken.

Ik dank de onderzoekers hartelijk voor hun voortvarende werk, en speciaal de familie Verbeek voor het vriendelijk ter beschikking stellen van hun bedrijf voor deze studie.

Bram Bos (projectleider) 


\section{Samenvatting}

Kippen scharrelen van nature hun voedsel bij elkaar door zowel met de poten als de snavel de bodem te bewerken. Leghennen in de commerciële leghennenhouderij krijgen hun voer aangeboden in voergoten of voerpannen. Tijdens de opname van dit voer kan de hen niet alle aspecten van het normale foerageergedrag vertonen. In scharrelsystemen oefenen de hennen dit foerageer- of scharrelgedrag meestal uit in het substraat op de vloer en, waar aanwezig, in de overdekte uitloop of in de buitenuitloop. Soms wordt graan gestrooid om het scharrelgedrag te belonen.

In het project 'Gezondheid voor mens en dier door systeemverandering in de pluimveehouderij' wordt gewerkt aan alternatieven voor de huidige strooiselmest als scharrelsubstraat, waaruit de mest kan worden verwijderd om de fijnstof- en ammoniakemissie te reduceren.

In deze pilot is op één commercieel leghennenbedrijf, met DeKalb hennen van 48 weken oud in een stal met overdekte uitloop en buitenuitloop, gedurende drie weken nagegaan aan welk substraat de hennen de voorkeur gaven om foerageergedrag in uit te oefenen. De uitgeteste substraten waren: turf (ingeschat als aantrekkelijk om in te foerageren vanwege gelijkenis met een natuurlijke bodem), houtkrullen (gebruikt in diverse systemen), schelpen, diatomeeënaarde, boekweitdoppen, hydrokorrels, schors, lavasteentjes, gehakselde wilgentakjes en gerstenstro. In een week werden vier substraten aangeboden in bakken van één vierkante meter van $30 \mathrm{~cm}$ hoog met op de bodem een scharrelmatje. Daarbij werden altijd een bak met houtkrullen en een bak met turf als controle aangeboden omdat houtkrullen de huidige standaard is en turf een positieve controle. In de eerste week zijn de zes bakken, met - behalve voor houtkrullen $(5 \mathrm{~cm})$ - een laag van $15 \mathrm{~cm}$ substraat, op donderdag neergezet in de overdekte uitloop voor gewenning. Op maandag en dinsdag voor en na het verversen van de substraten zijn tellingen gedaan van het aantal hennen in de bakken en het aantal hennen dat foerageergedrag of stofbadgedrag vertoonde (serie 1). In de tweede week werden de andere vier substraten, naast houtkrullen en turf, op dezelfde wijze aangeboden (serie 2). In de derde week werden de twee controles en de twee foerageerfavorieten uit week 1 en week 2 aangeboden (serie 3). Deze pilot geeft aan dat diatomeeënaarde, turf, schelpen en boekweitdoppen beter tegemoet lijken te komen aan de scharrelbehoefte van de leghennen dan houtkrullen, hydrokorrels, schors en lavasteentjes. Maar er was geen significant verschil in gebruik tussen diatomeeënaarde, turf, schelpen, gehakseld stro of boekweitdoppen onderling om in te foerageren. Deze pilot geeft aanleiding voor verder onderzoek naar preferente eigenschappen van foerageersubstraten voor leghennen. 


\section{$1 \quad$ Inleiding}

Kippen scharrelen van nature hun voedsel bij elkaar door zowel met de poten als de snavel de bodem te bewerken. Dit scharrelgedrag wordt onder natuurlijke omstandigheden meestal gecombineerd met exploratiegedrag. Foerageergedrag is strikt genomen het scharrelgedrag waarbij (eetbare) deeltjes worden opgenomen. In dit rapport worden de termen scharrelen en foerageren echter uitwisselbaar gebruikt.

Leghennen in de commerciële leghennenhouderij krijgen hun voer aangeboden in voergoten of voerpannen. Tijdens de opname van dit voer kan de hen niet alle aspecten van het normale foerageergedrag vertonen. In scharrelsystemen oefenen de hennen foerageergedrag meestal uit in het substraat op de vloer en, waar aanwezig, in de overdekte uitloop of in de buitenuitloop. Soms wordt graan gestrooid om het foerageergedrag te belonen.

Het normale bodemstrooisel in een scharrelstal bestaat meestal uit een dun laagje zand of houtkrullen bij aanvang van de ronde. De strooisellaag raakt gedurende de (leg)ronde steeds meer vervuild door uitwerpselen waardoor de hen uiteindelijk foerageert in een laag (droge) mest. Uit de literatuur is bekend dat hennen de voorkeur geven aan substraat zonder uitwerpselen om in te foerageren (von Waldburg-Zeil et al. 2019).

Volgens de Europese richtlijn moeten de hennen strooisel, bestaande uit los, manipuleerbaar materiaal tot hun beschikking hebben (E.U. 1999). En voor verrijkte kooien moet dat een met strooisel bedekte ruimte zijn waar de kippen kunnen scharrelen en bodempikken.

In het project 'Gezondheid voor mens en dier door systeemverandering in de pluimveehouderij' wordt gewerkt aan alternatieven voor de huidige strooiselmest als scharrelsubstraat. Doelstelling is om een scharrelruimte aan te kunnen bieden, waar de mest frequent (bijvoorbeeld dagelijks) uit verwijderd kan worden, terwijl het scharrelsubstraat blijft liggen (of gereinigd terugkeert in de ruimte). Op die manier wordt de fijnstofemissie van pluimveestallen bij de bron aangepakt, aangezien de fijnstofemissie van legpluimveestallen voor bijna $90 \%$ voortkomt uit pluimveemest, die de lucht in komt door scharrel- en stofbadgedrag van de hennen. Een tweede oogmerk is de ammoniakemissie uit pluimveestallen te reduceren, door de mest frequent uit de strooisellaag te verwijderen.

Voor het ontwerp van een dergelijke scharrelruimte, en de technieken om de mest uit het substraat te verwijderen, is het ook noodzakelijk om een goed inzicht te krijgen in de voorkeuren van leghennen voor de aard van het scharrelsubstraat. Daarover is tot nu toe nauwelijks informatie beschikbaar uit wetenschappelijke literatuur, in tegenstelling tot de voorkeur voor stofbadsubstraat waar wel veel informatie over bestaat (de Jong et al. 2007; Guinebretière et al. 2014; Gunnarsson et al. 2000; Scholz et al. 2010; Schutz and Jensen 2001).

Het doel van deze korte pilot is het vaststellen wat de relatieve voorkeur is van leghennen voor substraten om in te foerageren. Deze pilot studie is uitgevoerd in één vrije uitloop stal met witte leghennen, en resultaten kunnen daarom niet veralgemeniseerd worden. Uit de resultaten kan alleen een indruk verkregen worden over de relatieve voorkeur van dit type leghen, op deze leeftijd, gehouden onder deze omstandigheden, voor aangeboden soorten substraat. Vanwege de opzet en inrichting als pilotproef worden kwalitatieve verschillen in gedrag maar in beperkte mate vastgelegd.

Deze pilot moet leiden tot één of enkele substraten die (1) voldoen aan de scharrelbehoefte van de leghen, (2) leiden tot een lage (fijn)stofproductie en (3) eventueel gemakkelijk na gebruik gereinigd kunnen worden. Verdere toetsing zal moeten uitwijzen of deze voorkeuren gelden voor meerdere rassen leghennen en onafhankelijk zijn van het houderijsysteem of de voorgeschiedenis van de hennen (opfok). Eén van deze substraten kan verder worden getoetst in de systeembeoordeling van 'Code 2+'. 


\section{Materiaal en methoden}

\subsection{Praktijkbedrijf}

De pilot werd uitgevoerd op één praktijkbedrijf. Dit bedrijf had een stal van 85 meter lang met 4 gangen met daaraan aan één zijde een 7 meter brede overdekte uitloop (wintergarten) (zie figuur 2). De stal (en de overdekte uitloop) was verdeeld in 6 afdelingen. Via de overdekte uitloop konden de hennen naar buiten (zie figuur 1). In de overdekte uitloop was een drinklijn aanwezig en er lagen pikstenen. Per afdeling hing een net waar normaal luzerne in zit, maar dat gedurende de pilot leeg was. De strooisellaag in de overdekte uitloop was ongeveer $3 \mathrm{~cm}$ dik en droog en rul gedurende de pilot. De toegang tot de overdekte uitloop werd dagelijks rond 10 uur geopend, de buitenuitloop stond altijd open.

De 24.000 witte leghennen waren van het type DeKalb en waren bij de start van de pilot 48 weken oud. De pilot werd uitgevoerd in mei/juni 2019.

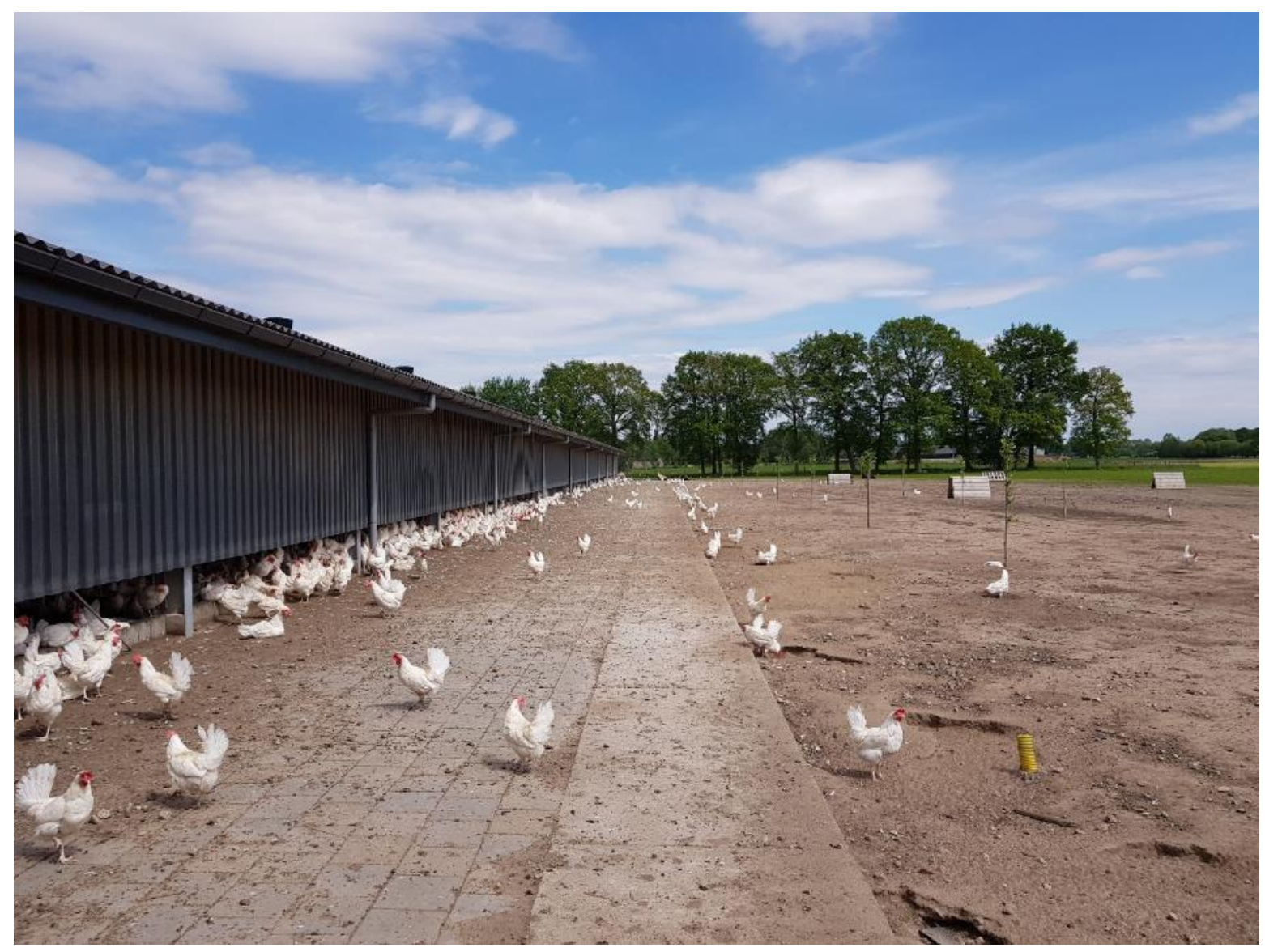

Figuur 1 De uitloop van het praktijkbedrijf met de ingang naar de overdekte uitloop. 


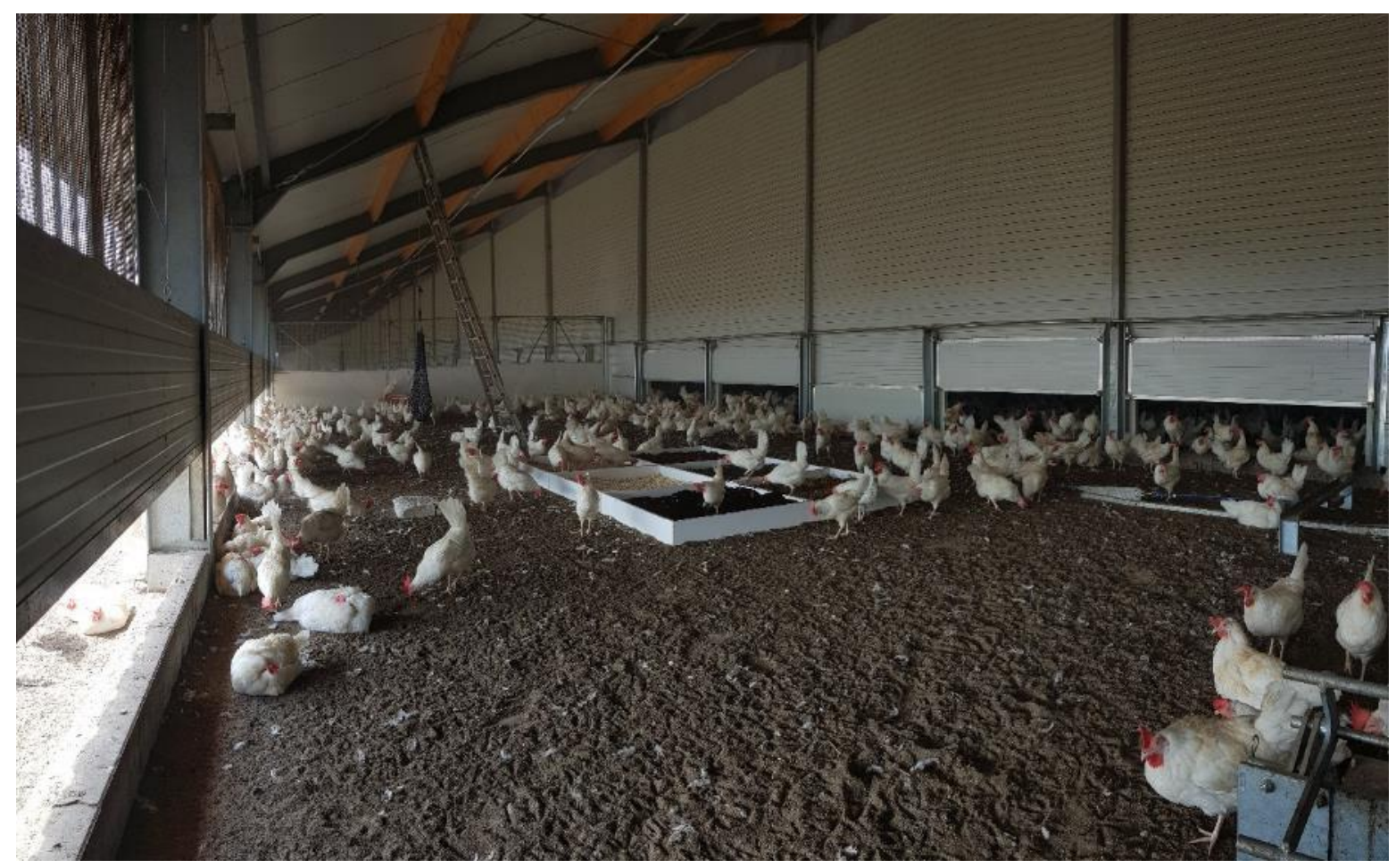

Figuur 2 De overdekte uitloop van het praktijkbedrijf met de openingen naar de stal en de uitloop.

\subsection{Scharrelsubstraten}

Een lijst met mogelijke scharrelsubstraten die waarschijnlijk voldoen aan de eisen die leghennen stellen en bruikbaar lijken in een alternatief ontwerp voor het scharrelgebied, werden aangeleverd door Departement Plantenwetenschappen, onderdeel Agrarische Bedrijfstechnologie en Wageningen Food and Biobased Research.

Voor de keuze van de substraten is uitgegaan van:

Eisen van de leghen ten aanzien van eigenschappen van substraat om foerageergedrag (afwisselend pikken naar en krabben in het substraat, met het oogmerk om eetbare deeltjes te vinden) te kunnen uitvoeren (foerageer- of scharrelgedrag):

1. De leghen moet de karakteristieke schraapbeweging met de poten in het substraat kunnen uitvoeren;

2. De leghen moet door middel van pikgedrag in het substraat op zoek kunnen naar eetbare deeltjes;

3. Het substraat moet manipuleerbaar zijn, d.w.z. de hen moet het kunnen bewegen, vervormen, opeten, afbreken, o.i.d. Voorbeelden van niet manipuleerbaar substraat zijn rubberen matjes, wel manipuleerbaar substraat is bijvoorbeeld droge en rulle houtkrullen;

4. Het substraat mag geen schade toebrengen aan de hen, d.w.z. geen schade aan voetzolen (bv. wondjes) of leiden tot inname van schadelijke (toxische) stoffen of obstipatie;

5. Het foerageergedrag moet belonend zijn, d.w.z. het leidt voor de hen tot een positief gevoel door de eigenschappen die het heeft en/of de beloning die te vinden is door het foerageergedrag. 
Belangrijke aspecten, gebaseerd op update Programma van eisen voor de leghen (Weeghel, De Jong, in prep.):

- $\quad$ Foerageren is gedrag waar het dier intern zeer gemotiveerd voor is om te vertonen. Ook gedomesticeerde lijnen laten foerageergedrag zien, zelfs als voldoende voer vrij beschikbaar is. Van nature wordt het gedrag gedurende een groot deel van de actieve periode uitgevoerd;

- $\quad$ Er zijn beperkte aanwijzingen dat een dikkere strooisellaag $(10 \mathrm{~cm})$ beter wordt gebruikt om te scharrelen (en stofbaden) dan $<5 \mathrm{~cm}$, maar voor foerageren is nog onvoldoende vastgesteld naar welke laagdikte de voorkeur van de hen uitgaat;

- $\quad$ Bij vergelijking van beperkt aantal typen substraten vertoonden hennen een voorkeur voor manipuleerbaar boven niet-manipuleerbaar materiaal;

- $\quad$ Vinden van beloning werkt stimulerend op het gedrag.

De uitgeteste substraten zijn (zie figuur 3):
A. Houtkrullen (controle 1 )
B. Turf (controle 2)
C. Boomschors
D. Gerstenstro gehakseld
E. Schelpen
F. Hydrokorrels
G. Wilgentakjes gehakseld
H. Diatomeeënaarde (mengsel met klei) korreltjes
I. Lavasteentjes
J. Boekweitdoppen

In deze pilot werden turf en houtkrullen steeds als controle meegenomen. Het laagje houtkrullen was slechts ongeveer 5 centimeter om de situatie zoals gebruikt wordt in het huidige Veranda systeem na te bootsen. Van de andere substraten werd een laag van $15 \mathrm{~cm}$ aangehouden. 

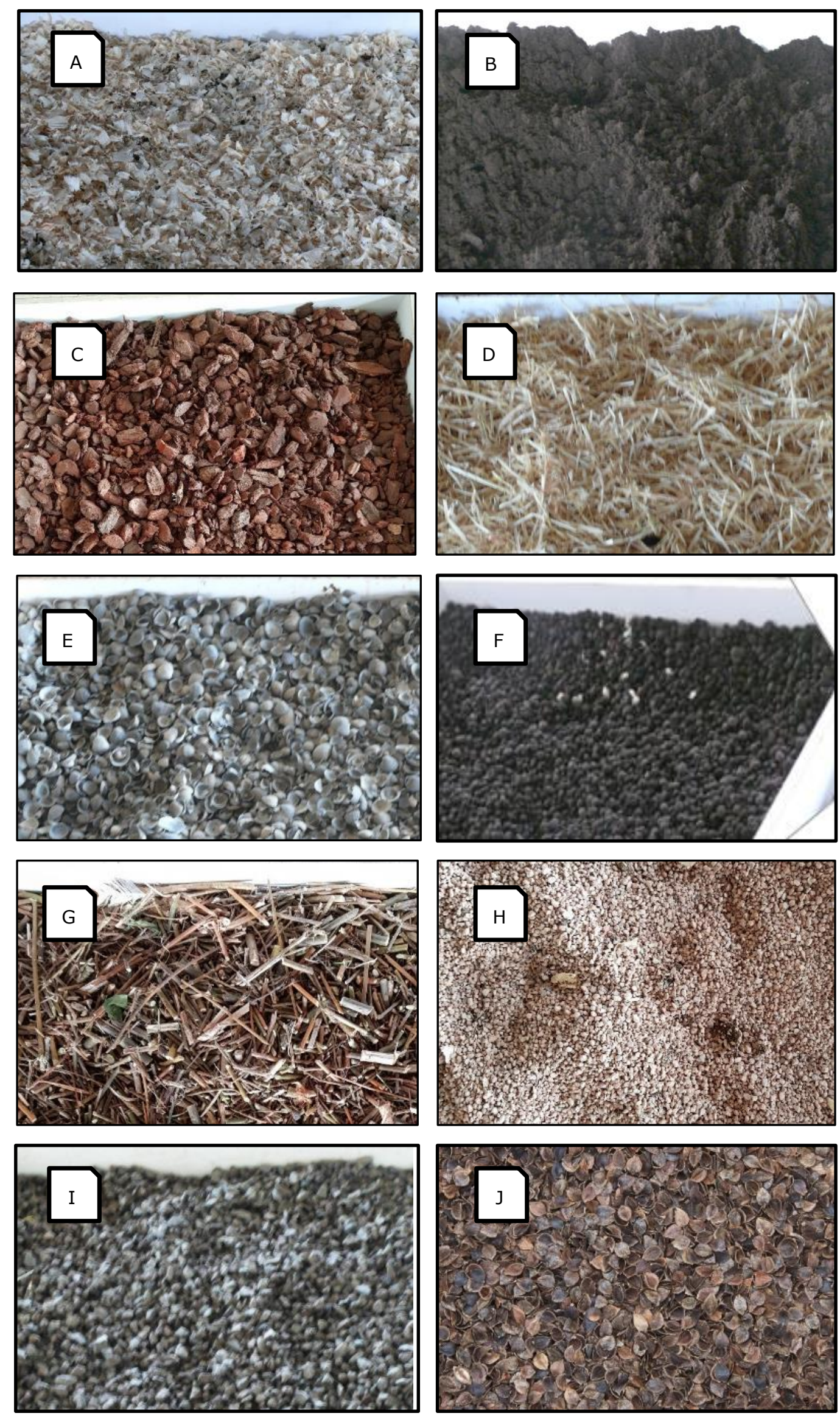

Figuur 3 De in de pilot aangeboden substraten: Houtkrullen, Turf, Boomschors, Gerstenstro, Schelpen, Hydrokorrels, Wilgentakjes gehakseld, Diatomeeënaarde (mengsel met klei) korreltjes, Lavasteentjes, Boekweitdoppen. 


\subsection{Bakken}

Het scharrelsubstraat werd steeds in 6 bakken aan de hennen aangeboden. De bakken waren van hout met een witte afwerklaag en hadden het formaat van $100 \mathrm{~cm}$ x $100 \mathrm{~cm}$ met een opstaande rand van 30 centimeter.

Onderin alle bakken werd een zogenaamd 'AstroTurf poultry pad' gelegd. Dit is het huidige scharrelmatje in het Verandasysteem en wordt ingestrooid met houtkrullen. In de pilot werd een laag substraat van $15 \mathrm{~cm}$ (of $5 \mathrm{~cm}$ als het de houtkrullen betrof) aangebracht.

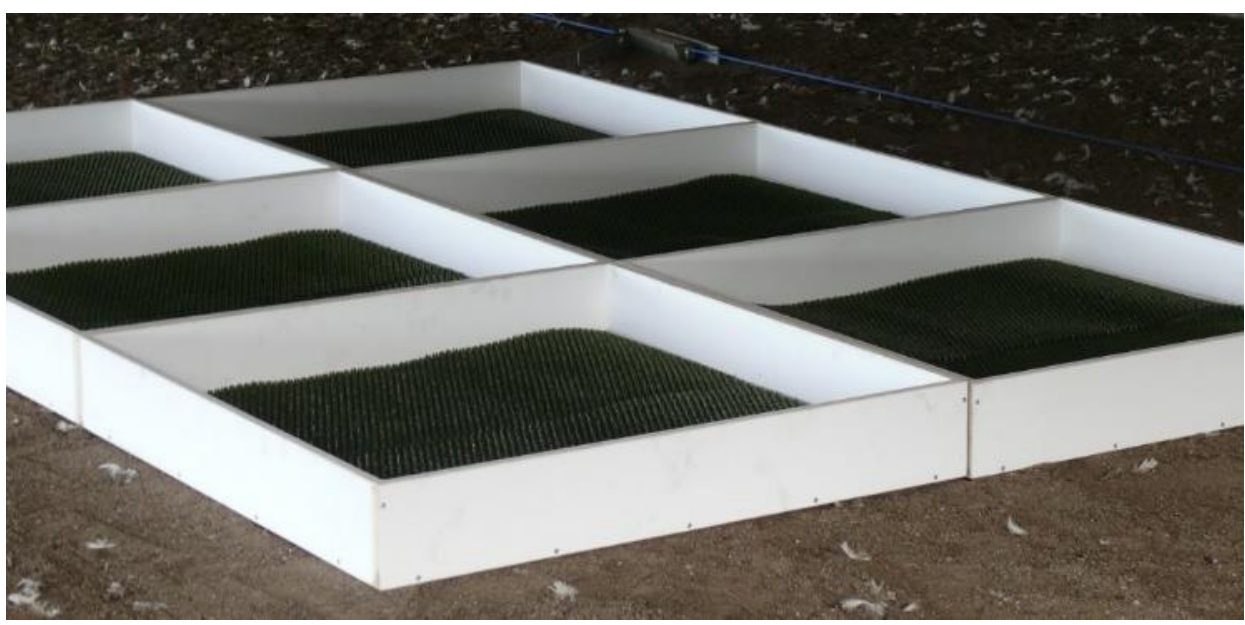

Figuur 4 Opstelling in serie 1 en 2 van lege bakken met het formaat van $100 \mathrm{~cm} \times 100 \mathrm{~cm}$ en met een opstaande rand van $30 \mathrm{~cm}$ met daarin 'AstroTurf poultry pads' matjes.

\section{$2.4 \quad$ Opzet pilot}

De voorkeur van de hennen voor een 8-tal substraten werd op het praktijkbedrijf in drie opeenvolgende series getest. Een set van 6 bakken met substraat (inclusief de 2 controles) werd neergezet in de overdekte uitloop. Dit is een zone waarin voldoende licht en ruimte is en aangenomen kon worden dat dit de plek is waar hennen scharrelgedrag zouden willen uitvoeren. Vanuit de overdekte uitloop konden de hennen naar de buitenuitloop. De overdekte uitloop, waarbij tegelijk de buitenuitloop bereikbaar werd, ging om 10 uur 's ochtends open.

Gestart werd met twee series (week 1 en 2) met een vergelijking van een 4-tal substraten (en de twee controles), gevolgd door een serie (week 3) met de vergelijking van de twee beste substraten per week (en de twee controles) uit de twee eerste series. De substraten werden op 16 mei, 23 mei en 30 mei klaar gezet waarna na het weekend de waarnemingen plaats vonden op 20 en 21 mei, 27 en 28 mei en 3 en 4 juni 2019.

De verdeling van het type substraat over de 6 bakken was in eerste instantie random, de tweede meetdag wisselden alle substraten van plaats.

De 6 bakken met daarin de substraten werden voor het eerst op donderdag 16 mei in de overdekte uitloop geplaatst voordat de uitloop werd geopend. Na het openen van de uitloop konden de hennen wennen aan de opzet en kon worden nagegaan wanneer de hennen het meeste foerageergedrag vertoonden. Aan de hand hiervan werd bepaald welke tijdspanne voor de verdere waarnemingen gehanteerd werd. Volgens de leghennenhouder zijn de hennen rond 14-15 uur 's middags meestal binnen, en gaan na 16 uur de meeste dieren naar buiten. Volgens de literatuur foerageren de hennen het meeste 6 uur nadat de lichten aan zijn gegaan (Pokharel et al. 2017). Op het praktijkbedrijf, waar het licht om 6 uur aangaat, zou dat betekenen dat om 12 uur de meeste hennen foerageren. Uit de waarnemingen op de eerste dag, bleken de hennen op dit bedrijf inderdaad in de middag meer te scharrelen dan in de ochtend. 
De eerste twee series zijn de zes bakken zonder tussenruimte naast elkaar geplaatst (zie figuur 4 en figuur 5). Door het scharrelgedrag werden de substraten gedeeltelijk vanuit de ene bak naar de andere bak verplaatst. Om deze 'vervuiling' van de substraten te voorkomen is in de derde serie gekozen om de bakken $50 \mathrm{~cm}$ uit elkaar te plaatsen (zie figuur 6).

De opzet van deze pilot is dusdanig van aard (geheel niet invasief en geen handling van hennen) dat dit niet gezien wordt als een dierproef. 


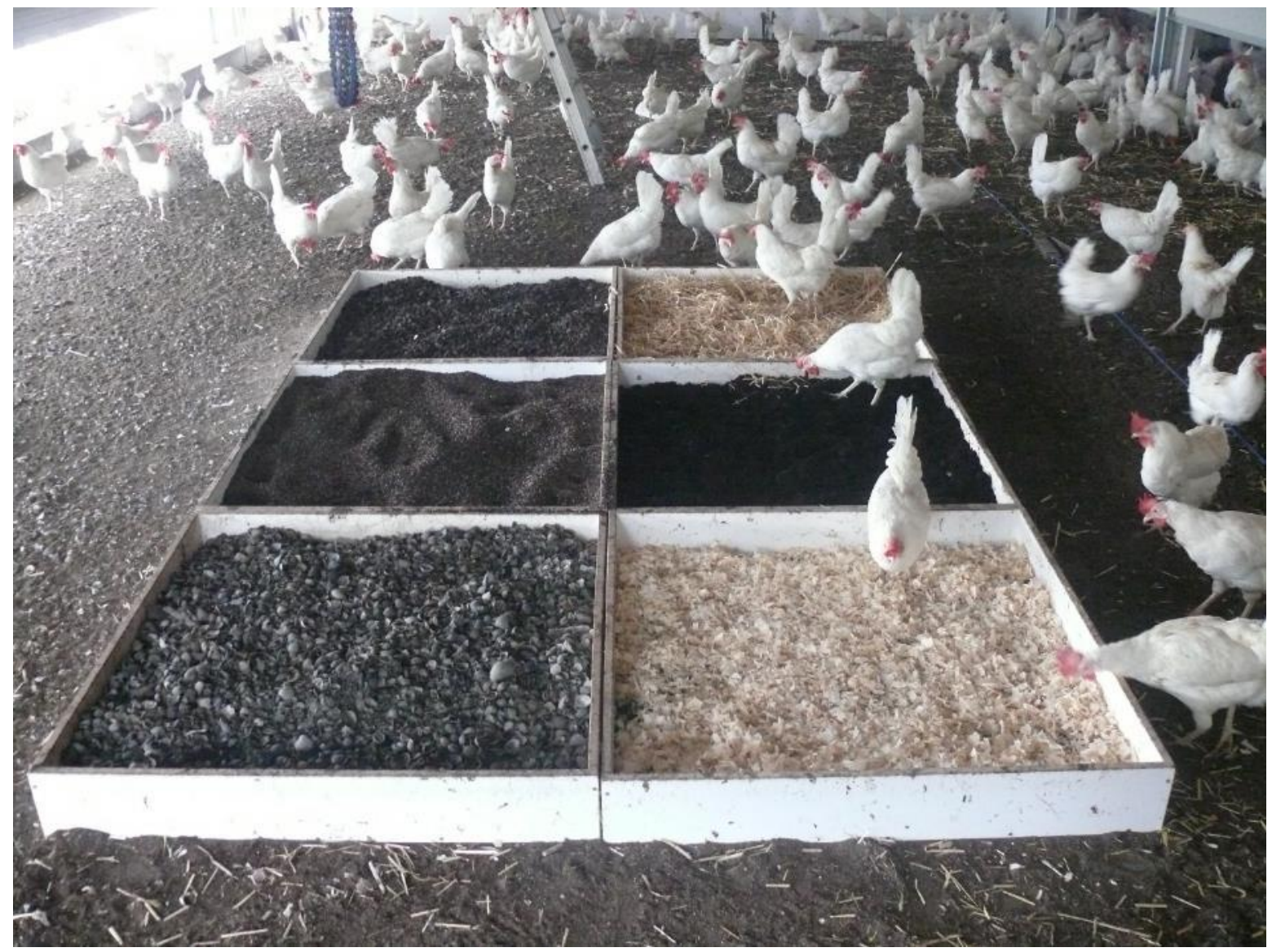

Figuur 5 Het aanbieden van 6 verschillende substraten in serie 1 en 2 in de overdekte buitenuitloop waarbij de bakken tegen elkaar aanstaan.

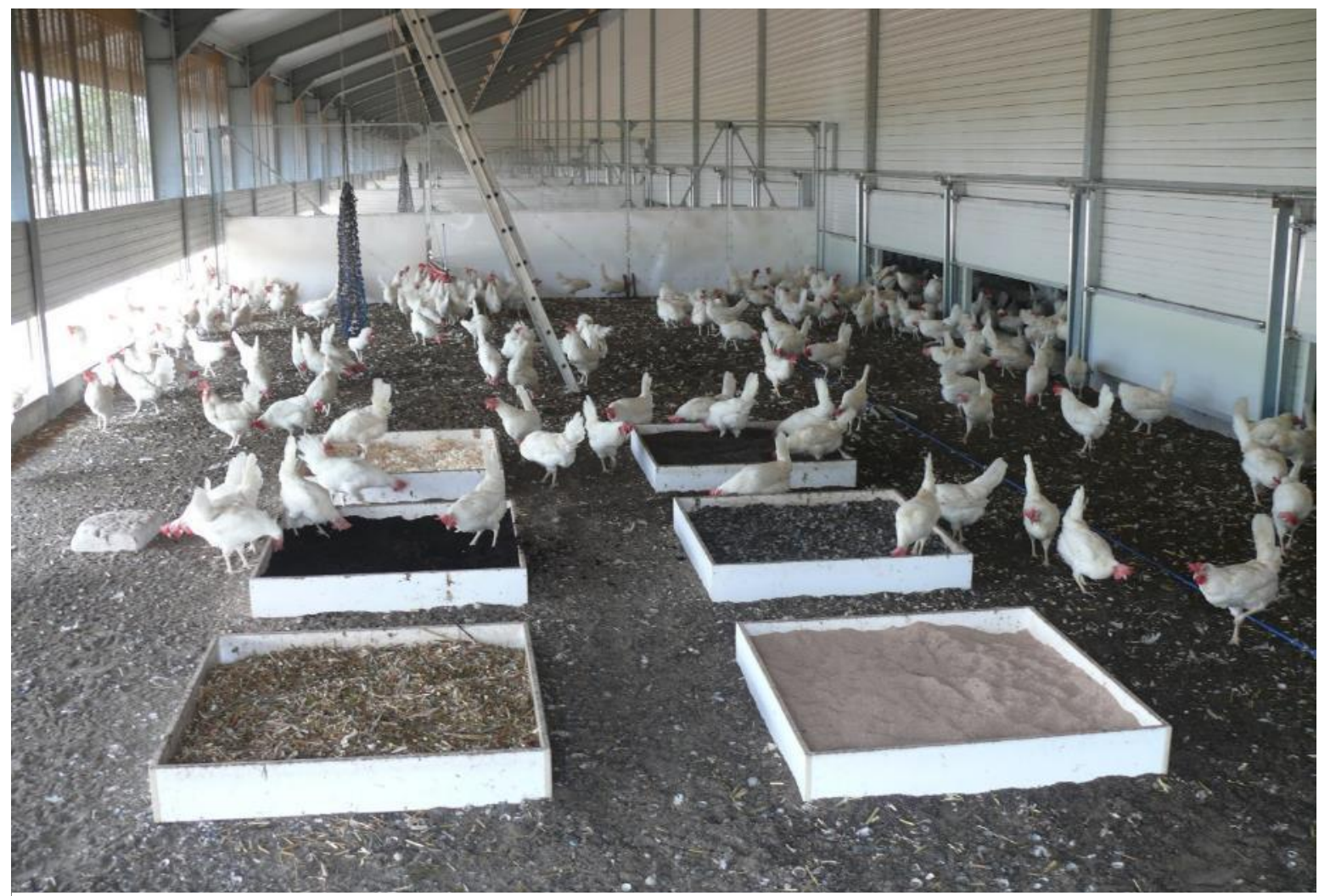

Figuur 6 Het aanbieden van 6 verschillende substraten in serie 3 in de overdekte buitenuitloop waarbij de bakken 50 centimeter uit elkaar staan. 


\subsection{Gedragswaarnemingen}

Elk half uur, startend om 10.30 uur, werd het totaal aantal hennen drie keer geteld in elk van de 6 bakken, en het aantal hennen in iedere bak dat foerageergedrag of stofbadgedrag vertoonde. Daarna werd het aantal hennen geteld in de vooraf bepaalde afgebakende omgeving. De afgebakende omgeving bevatte een ruimte van ongeveer één meter rondom de bakken, visueel begrenst door pikblok, kabel mestschuif en spanten.

Het aantal hennen dat zich in de bakken met verschillende substraten en om de bakken heen bevond en het aantal dat scharrelgedrag, stofbadgedrag of ander gedrag vertoonde in een bak, is geteld. De tellingen zijn verricht in 3 series, steeds per week op 2 achtereenvolgende dagen. De eerste 3 waarnemingen op een dag hebben plaats gevonden 30 minuten na het openen van de uitloop in nog niet ververst substraat. Na het verschonen van de substraten zijn 21 tellingen per bak met substraat en 21 maal de omgeving van de bakken gedaan in de tijd range van 13:00 tot en met 16:00 uur. In totaal zijn 1008 waarnemingen gedaan.

Voorafgaand aan de gedragswaarnemingen werd enige habituatietijd in acht genomen, zodat de hennen 'zo ongestoord mogelijk' waargenomen werden.

Tabel 1 Het waarneemschema van het aantal en gedrag van de hennen in en om de 6 bakken.

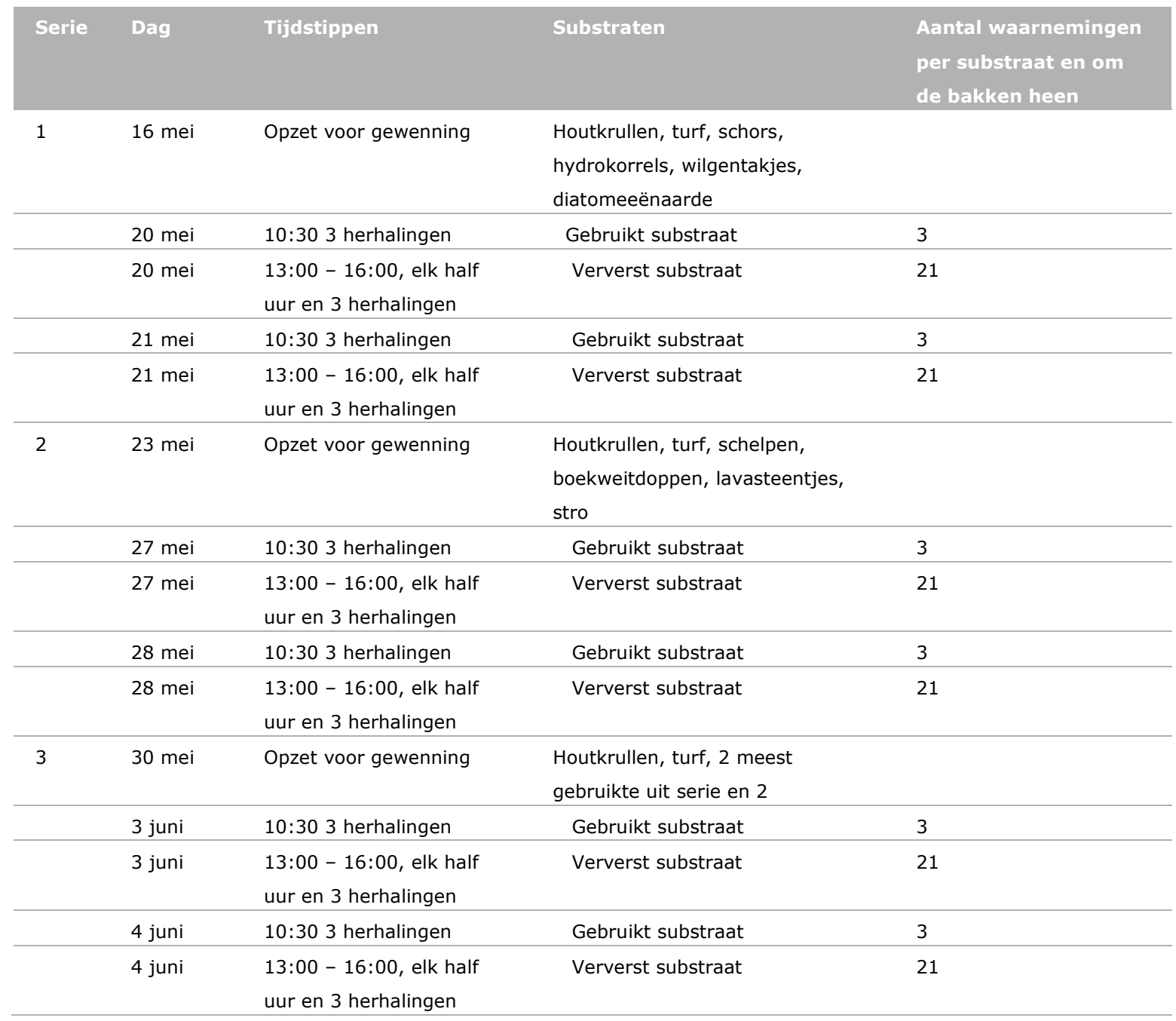




\subsubsection{Ethogram}

In tabel $\mathbf{2}$ is het ethogram dat is gebruikt in deze proef weergegeven.

\section{Tabel 2 Ethogram.}

\begin{tabular}{ll} 
Gedrag & Definitie \\
Foerageren & Afwisselend krabben en pikken in substraat \\
\hline Stofbaden & $\begin{array}{l}\text { Liggen zijwaarts, inschudden, krabben, vleugels bewegen, kop en nek tegen de grond, } \\
\text { uitschudden volgens Van Liere (Van Liere, 1991) }\end{array}$ \\
\hline Overig & Zitten/staan, lopen of pikken naar iets anders dan substraat \\
\hline Op rand bak & Het aantal hennen dat van buiten de bak of vanaf de bakrand het substraat \\
& manipuleerde \\
\hline Aantal hennen rondom bak & $\begin{array}{l}\text { Aantal hennen in denkbeeldige ruimte van één meter rondom bak(ken) dat } \\
\text { foerageergedrag vertoont }\end{array}$ \\
\hline
\end{tabular}

\subsubsection{Beeldmateriaal verzamelen}

Tijdens de bezoekdagen werd ook beeldmateriaal verzameld. De waarnemer maakte vooraf en na het uitvoeren van de tellingen foto's van de bakken, de ruimte eromheen, etc. (detail en overzicht).

Daarnaast werd een camcorder op statief opgezet om video opnames te maken tijdens het uitvoeren van de tellingen, dit voor latere communicatie doeleinden.

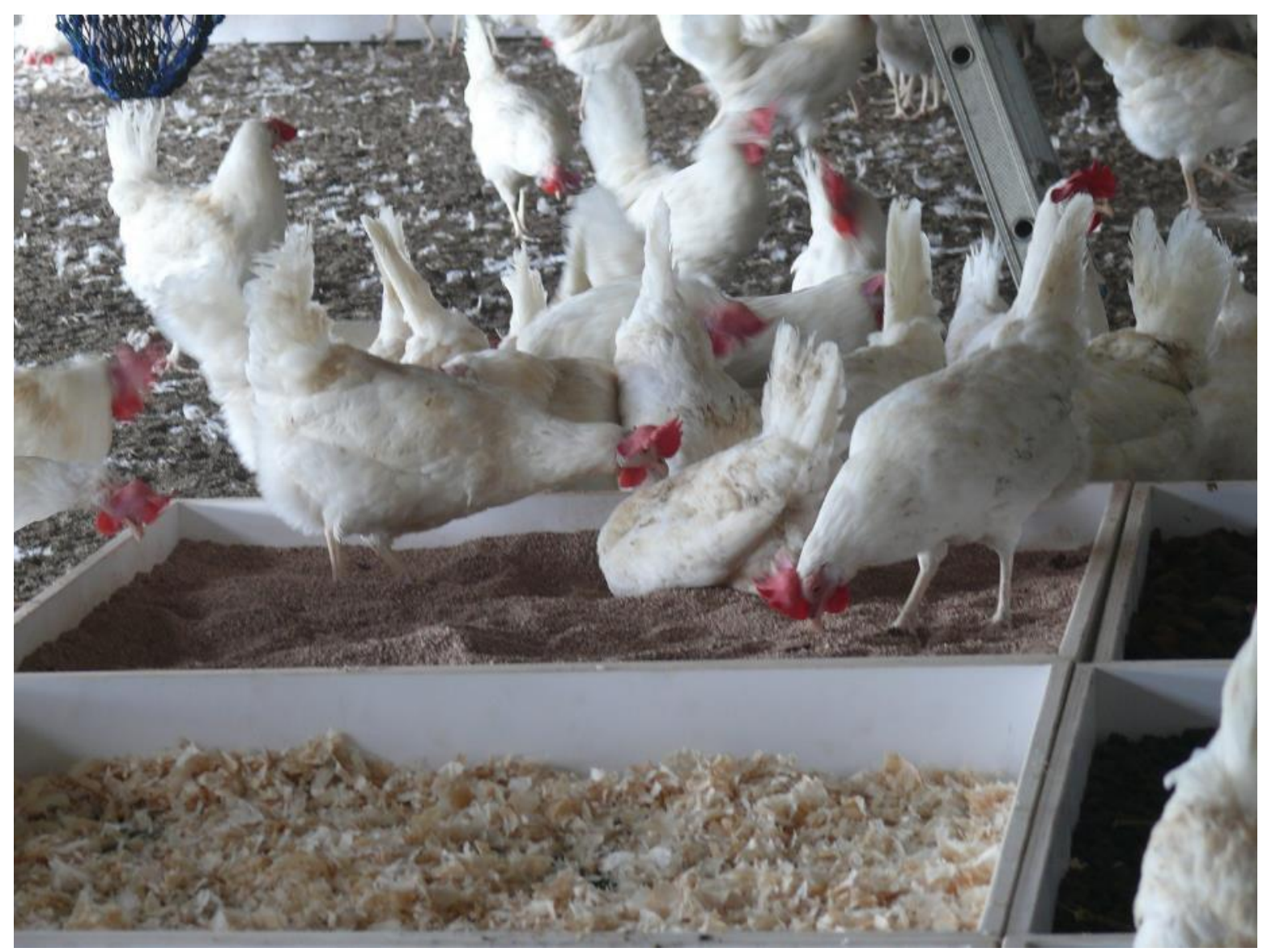

Figuur 7 Een momentopname waarin een tweetal hennen foerageergedrag vertoont en één hen stofbadgedrag vertoont in de bak met diatomeeënaarde (mengsel met klei) korreltjes. 


\subsection{Analyse voorkeur hennen}

Het gemiddelde van het aantal hennen (en uitgesplitst naar gedrag volgens het ethogram) per substraat zijn de uitkomstvariabelen. Aanname was dat de invloed van week minimaal zou zijn en voor deze pilot voldoende te hebben aan het herhalen van de 2 controles in alle series.

Analyse van het aantal foeragerende hennen per substraat (na verversing) is gedaan na een logtransformatie van de aantallen via een variantie componenten analyse waarbij rekening werd gehouden met de datum waarop de waarnemingen plaats vonden (Random factor) (REML, Genstat 19th Edition, 2018).

\subsection{Beperkingen}

Een beperking van de proef is dat de pilot heeft plaats gevonden bij een bestaand koppel van een bepaalde leeftijd (bij de start 48 weken), opfok en een bepaald ras (DeKalb) en bij een bepaald soort verlichting. De resultaten zijn daarom slechts indicatief en niet algemeen toepasbaar.

Op het betreffende bedrijf wordt normaal éénmaal daags graan gestrooid, maar gedurende de waarnemingsdagen is geen graan gestrooid in de uitloop waar de waarnemingen plaats vonden. De reden hiervoor was om geen verstoring te hebben bij de waarnemingen door de reactie van de hennen op het strooien van graan. 


\section{Resultaten}

\subsection{Waarnemingen per substraat}

Gemiddeld werden in serie 1 en 2 (in gebruikt en ververst substraat) 1,8 hennen per bak waargenomen waarvan 1,7 foerageergedrag vertoonden en gemiddeld maar 0,005 hen stofbadgedrag. Daarnaast werden 0,6 hennen geteld die van buiten de bak of vanaf de rand van de bak in het substraat pikten. Het aantal hennen in de omgeving van de bakken was gemiddeld 25,5 hennen.

Als alleen gekeken werd naar het aantal hennen en het gedrag bij ververst substraat in serie 1 en 2 dan werden er ook 1,8 hennen per bak waargenomen waarvan 1,7 foerageergedrag vertoonden. Daarnaast werden 0,7 hennen geteld die van buiten de bak of vanaf de rand van de bak in het substraat pikten. Het aantal hennen in de omgeving van de bakken na verversen van het substraat was gemiddeld 27,0 hennen.

In de eerste twee series werd alleen stofbadgedrag in ververst substraat waargenomen in diatomeeënaarde.

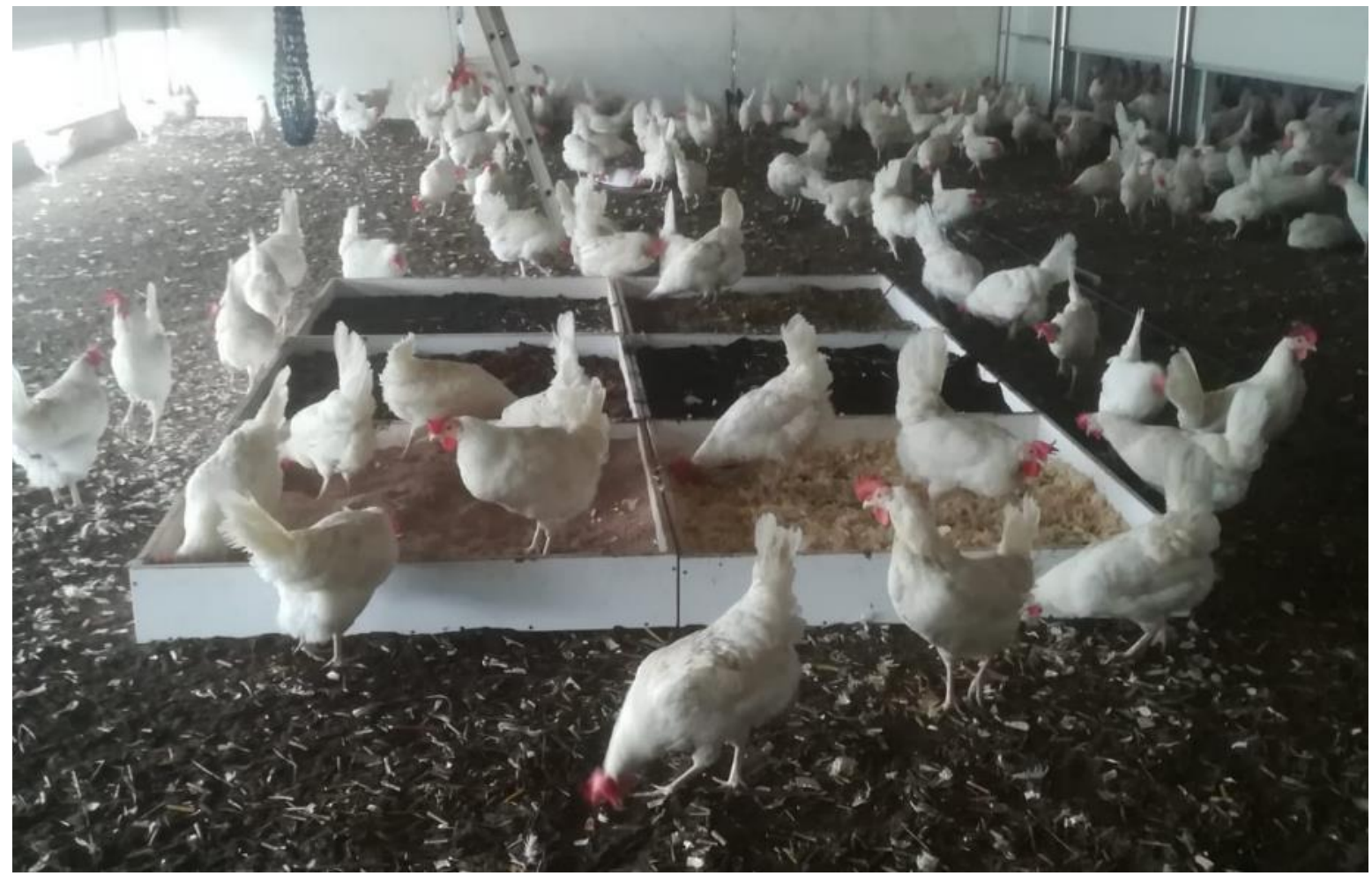

Figuur 8 Foeragerende hennen in de bakken en hennen die van buiten de bak in de bak pikken.

Gezien het lage aantal waarnemingen bij gebruikt substraat is de analyse verder op de waarnemingen gedaan na het verversen van de substraten. En gezien het kleine verschil tussen het totaal aantal hennen en het aantal foeragerende hennen is voor de verdere analyse gekozen voor het aantal foeragerende hennen als uitkomstvariabele. 
Tabel 3 Gemiddeld aantal waargenomen hennen, foeragerende hennen en hennen op de rand van de bakken of erbuiten pikkend in substraat per substraat en het gemiddeld aantal hennen waargenomen in de omgeving van de bakken in serie 1 en 2 voor en na het verversen van het substraat (gebruikt / ververst substraat).

\begin{tabular}{|c|c|c|c|c|c|}
\hline Serie & Substraat & $\begin{array}{l}\text { Aantal } \\
\text { waarnemingen }\end{array}$ & $\begin{array}{l}\text { Gemiddeld } \\
\text { aantal hennen }\end{array}$ & $\begin{array}{l}\text { Gemiddeld aantal } \\
\text { foeragerende } \\
\text { hennen }\end{array}$ & $\begin{array}{l}\text { Gemiddeld aantal } \\
\text { hennen op de rand } \\
\text { of buiten de bak }\end{array}$ \\
\hline 1 & omgeving & $6 / 42$ & $12,3 / 23,0$ & & \\
\hline 1 & houtkrul & $6 / 42$ & $1,5 / 1,8$ & $0,8 / 1,6$ & $0 / 0,6$ \\
\hline 1 & turf & $6 / 42$ & $0,2 / 1,6$ & $0,2 / 1,5$ & $0,3 / 0,6$ \\
\hline 1 & wilgentakjes & $6 / 42$ & $1,0 / 1,7$ & $1,0 / 1,6$ & $0,5 / 1,1$ \\
\hline 2 & omgeving & $6 / 42$ & $18,3 / 31,0$ & & \\
\hline 2 & houtkrul & $6 / 42$ & $1,2 / 1,8$ & $1,7 / 1,7$ & $0,3 / 0,4$ \\
\hline 2 & lava & $6 / 42$ & $0,8 / 0,5$ & $0,8 / 0,4$ & $0,7 / 0,05$ \\
\hline 2 & schelpen & $6 / 42$ & $2,7 / 2,0$ & $2,7 / 2,0$ & $0,7 / 0,5$ \\
\hline 2 & turf & $6 / 42$ & $1,5 / 2,0$ & $1,5 / 1,9$ & $0,5 / 0,6$ \\
\hline
\end{tabular}

Op basis van het gemiddeld aantal foeragerende hennen in ververst substraat zijn in serie 1 diatomeeënaarde en wilgentakjes uitgekozen en in serie 2 boekweitdoppen en schelpen om getest te worden in serie 3.

Tabel 4 Gemiddeld aantal waargenomen hennen, foeragerende hennen en hennen op de rand van de bakken of erbuiten pikkend in substraat per substraat en het gemiddeld aantal hennen waargenomen in de omgeving van de bakken in serie 3 voor en na het verversen van het substraat (gebruikt / ververst substraat)

\begin{tabular}{llllll} 
Serie & Substraat & $\begin{array}{l}\text { Aantal } \\
\text { Waarnemingen }\end{array}$ & $\begin{array}{l}\text { Gemiddeld aantal } \\
\text { hennen }\end{array}$ & $\begin{array}{l}\text { Gemiddeld aantal } \\
\text { foeragerende } \\
\text { hennen }\end{array}$ & $\begin{array}{c}\text { Gemiddeld aantal } \\
\text { hennen op de } \\
\text { rand of buiten de } \\
\text { bak }\end{array}$ \\
\hline 3 & omgeving & $6 / 42$ & $18,8 / 32,6$ & $0,8 / 1,2$ \\
\hline 3 & boekweit & $6 / 42$ & $0,8 / 2,3$ & $0,8 / 2,2$ & $1,0 / 1,1$ \\
\hline 3 & diatomeeën & $6 / 42$ & $2,5 / 3,4$ & $1,7 / 2,8$ & $0,3 / 0,7$ \\
\hline 3 & houtkrul & $6 / 42$ & $1,2 / 1,3$ & $1,0 / 1,2$ & $0,7 / 1,3$ \\
\hline 3 & schelpen & $6 / 42$ & $1,8 / 3,1$ & $1,8 / 6,0$ & $1,7 / 5,5$ \\
\hline 3 & turf & $6 / 42$ & $1,7 / 6,3$ & $0,7 / 1,2$ & $0,3 / 1,1$
\end{tabular}

In serie 3 werd meer stofbadgedrag waargenomen dan in serie 1 en 2, maar stofbadgedrag werd alleen gezien in diatomeeënaarde en een enkele keer in turf.

\subsection{Analyse aantal foeragerende hennen}

Analyse van het aantal foeragerende hennen in ververst substraat in serie 1, 2 en 3 geeft de in figuur 9 weergegeven gemiddelde aantallen (de geschatte waarden op basis van de statistische analyse). Diatomeeënaarde, turf en schelpen werden significant meer gebruikt om in te foerageren vergeleken met houtkrullen, wilgentakjes, schors en lavasteentjes. Boekweitdoppen werden significant meer gebruikt om in te foerageren dan wilgentakjes, schors en lavasteentjes. Maar er was geen significant verschil in gebruik tussen diatomeeënaarde, turf, schelpen, gehakseld stro of boekweitdoppen om te foerageren. 


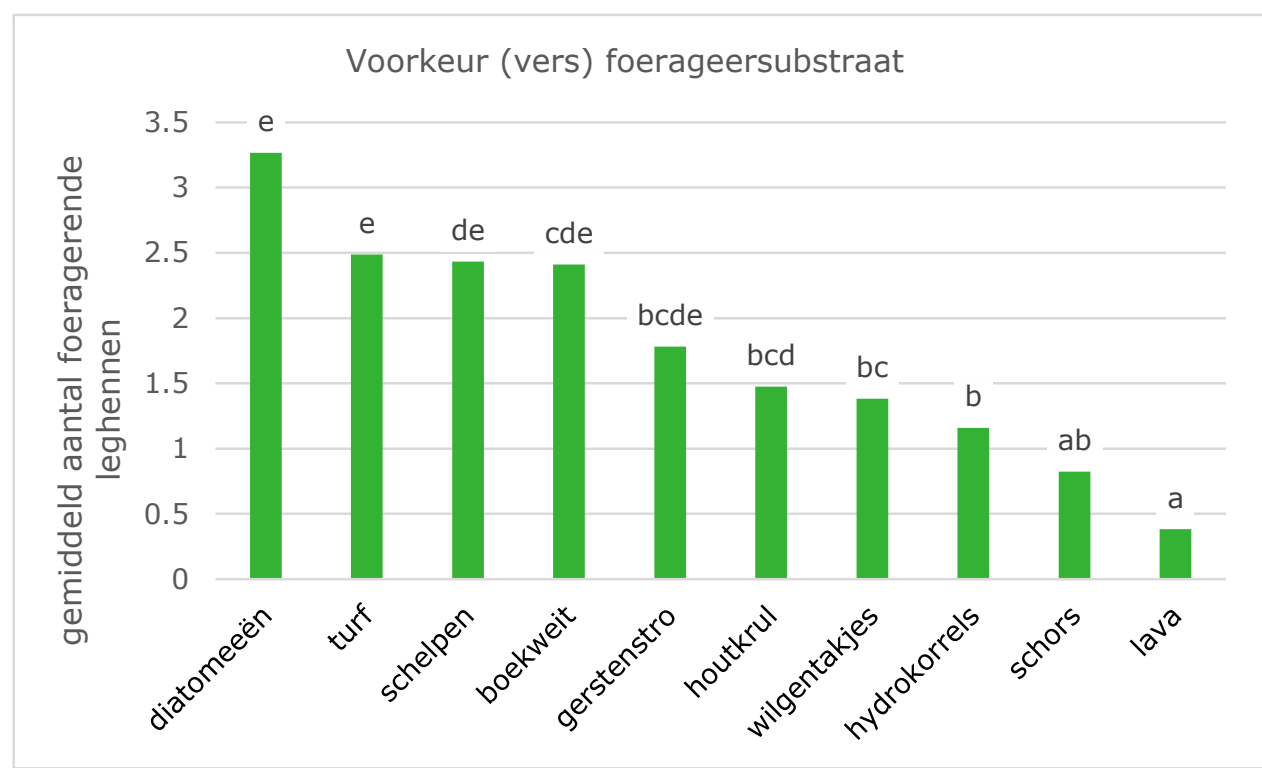

Figuur 9 Geschatte gemiddelde (op basis van de statistische analyse) van het aantal foeragerende hennen per substraat waarbij verschillende letters een significant verschil weergeven 


\section{Discussie en conclusie}

Deze pilot naar de voorkeur voor substraat om in te foerageren van DeKalb witte leghennen van bij de start 48 weken oud op één bedrijf in de overdekte uitloop, geeft een beeld dat de hennen inderdaad een substraatvoorkeur laten zien. De hennen in deze pilotstudie hadden voor hun foerageergedrag de voorkeur voor diatomeeënaarde, turf, schelpen en boekweitdoppen boven houtkrullen, hydrokorrels, schors en lavasteentjes. Houtkrullen worden in de praktijk veel gebruikt als substraat, maar deze pilot laat zien dat dit mogelijk niet het preferente substraat is van leghennen. In de praktijk worden de houtkrullen vermengd met mest en pure houtkrullen zijn ook alleen maar vlak na een verversing aanwezig, dus, de omstandigheden zijn niet volledig vergelijkbaar. Verder geven de resultaten aan dat grote partikels en ruwe oppervlaktes mogelijk minder worden geprefereerd (schors, lavasteen) en dat ronde harde korrels (hydrokorrels) ook niet de eigenschappen hebben die hennen prefereren.

Daarentegen lijken fijne substraten (diatomeeënaarde, turf) en middelgrote maar geen of minder ruwe substraten (schelpen, boekweitdoppen) ook de voorkeur te hebben. Daarnaast speelt het gewicht mogelijk een rol; de preferente substraten zijn (overwegend) relatief licht. Het is onduidelijk waarom houtkrullen, die toch relatief licht, niet ruw en niet groot zijn, niet geprefereerd worden. Wellicht heeft dit te maken met de aangeboden dikte van deze strooisellaag $(5 \mathrm{~cm}$ in plaats van $15 \mathrm{~cm}$ bij de andere substraten)

Gedurende de weken leek de activiteit in de bakken met substraten toe te nemen. Dit kan mogelijk te maken hebben met gewenning van de hennen aan de bakken of de waarnemer gedurende de looptijd van de pilotproef. Het is dan ook niet uit te sluiten dat de resultaten van de eerste week mogelijk niet vergelijkbaar zijn met de andere weken.

De waarnemer rapporteerde dat de hennen zeer geïnteresseerd leken in een afwijkend deeltje in een bak met substraat. Zo pikten ze bijvoorbeeld meer naar een houtkrul die terecht was gekomen in de bak met turf. Om deze voor de pilot verstorende factor van 'vervuiling' van de substraten onderling te verminderen is er daarom voor gekozen de bakken in serie 3 uit elkaar te plaatsen. Ook hier is het niet volledig uit te sluiten dat de resultaten hier niet door beïnvloed zijn.

In deze pilot hadden de hennen de keuze om in de stal, de overdekte uitloop of de buitenuitloop te zijn en was de strooisellaag in de stal en de overdekte uitloop droog. Het zou kunnen dat het aanbieden van scharrelsubstraat een ander resultaat oplevert in andere situaties, bijvoorbeeld in een relatief donkere binnenruimte of wanneer het strooisel is dichtgeslagen (en mogelijk minder aantrekkelijk is voor foerageren). Ook een andere ras hennen kan wellicht een ander resultaat opleveren.

Concluderend, deze pilot proef geeft een eerste inzicht in mogelijke voorkeuren van leghennen voor foerageersubstraat. Tot nu toe zijn daar nauwelijks wetenschappelijke publicaties over te vinden. Zo vond (De Jong, Wolthuis-Fillerup, Van Reenen, 2001) dat leghennen in gelijke mate scharrelden in turf, houtkrullen of zand. Een vergelijking met meer grove substraten, zoals in deze pilot, is echter voor zover wij weten nog niet eerder uitgevoerd. Het is daarom aan te bevelen om deze test te herhalen met zowel witte als bruine leghennen onder gestandaardiseerde proefcondities. Daarbij dient rekening gehouden te worden met de punten voor verbetering zoals hierboven is aangegeven. 


\section{Literatuur}

De Jong, I. C., M. Wolthuis-Fillerup, and C. G. van Reenen. 2007. Strength of preference for dustbathing and foraging substrates in laying hens. Applied Animal Behaviour Science 104 (1): 24-36. http://dx.doi.org/https://doi.org/10.1016/j.applanim.2006.04.027.

E.U. 1999. Richtlijn 1999/74/EG van de raad van 19 juli 1999 tot vaststelling van minimumnormen voor de bescherming van legkippen. . edited by Publicatieblad van de Europese Gemeenschappen (L 203): 53-57.

Genstat Nineteenth Edition. 2018.

Guinebretière, M., H. Beyer, C. Arnould, and V. Michel. 2014. The choice of litter material to promote pecking, scratching and dustbathing behaviours in laying hens housed in furnished cages. Applied Animal Behaviour Science 155: 56-65. http://dx.doi.org/https://doi.org/10.1016/j.applanim.2014.02.013.

Gunnarsson, S., L. R. Matthews, T. M. Foster, and W. Temple. 2000. The demand for straw and feathers as litter substrates by laying hens. Applied Animal Behaviour Science 65: 321330.

Pokharel, B. B., I. Boecker, I. Y. Kwon, L. Jeyachanthiran, P. McBride, and A. HarlanderMatauschek. 2017. How does the presence of excreta affect the behavior of laying hens on scratch pads? Poultry Science 97 (3): 743-748. http://dx.doi.org/10.3382/ps/pex375.

Scholz, B., S. Urselmans, J. B. Kjaer, and L. Schrader. 2010. Food, wood, or plastic as substrates for dustbathing and foraging in laying hens: A preference test. Poultry Science 89 (8): 1584-1589. http://dx.doi.org/10.3382/ps.2009-00598.

Schutz, K. E., and P. Jensen. 2001. Effects of resource allocation on behavioural strategies: A comparison of red junglefowl (Gallus gallus) and two domesticated breeds of poultry. Ethology 107: 753-765. http://dx.doi.org/doi 10.1046/j.1439-0310.2001.00703.

Van Liere, D. W. 1991. Function and organization of dustbathing in laying hens, Wageningen Agricultural University, Wageningen.

von Waldburg-Zeil, C. G., N. van Staaveren, and A. Harlander-Matauschek. 2019. Do laying hens eat and forage in excreta from other hens? animal 13 (2): 367-373. http://dx.doi.org/Doi: 10.1017/s1751731118001143.

Weeghel, E., and I. C. de Jong. in prep. Brief of Requirements of the laying hen. 

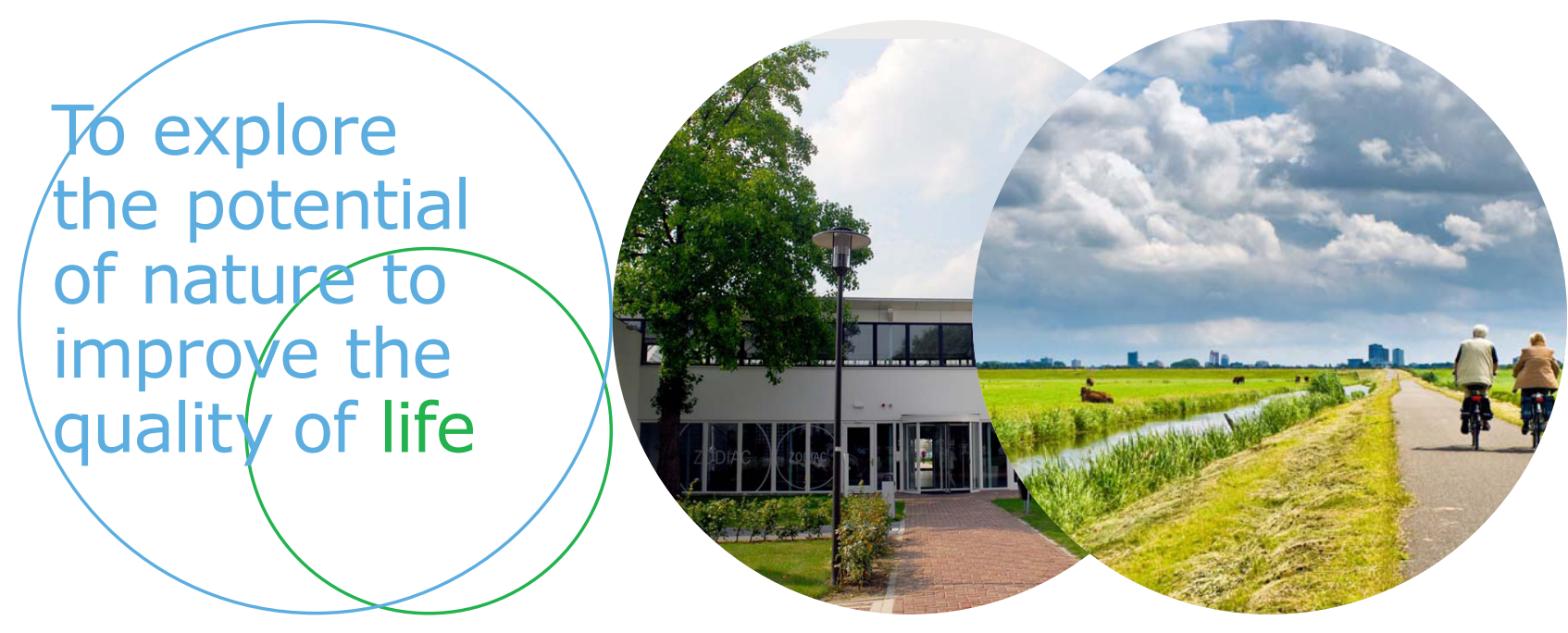

Wageningen Livestock Research Postbus 338

Wageningen Livestock Research ontwikkelt kennis voor een zorgvuldige en $6700 \mathrm{AH}$ Wageningen

T 0317483953

E info.livestockresearch@wur.nl www.wur.nl/ livestock-research renderende veehouderij, vertaalt deze naar praktijkgerichte oplossingen en innovaties, en zorgt voor doorstroming van deze kennis. Onze wetenschappelijke kennis op het gebied van veehouderijsystemen en van voeding, genetica, welzijn en milieu-impact van landbouwhuisdieren integreren we, samen met onze klanten, tot veehouderijconcepten voor de $21 \mathrm{e}$ eeuw.

De missie van Wageningen University \& Research is 'To explore the potential of nature to improve the quality of life'. Binnen Wageningen University \& Research bundelen 9 gespecialiseerde onderzoeksinstituten van Stichting Wageningen Research en Wageningen University hun krachten om bij te dragen aan de oplossing van belangrijke vragen in het domein van gezonde voeding en leefomgeving. Met ongeveer 30 vestigingen, 6.500 medewerkers en 10.000 studenten behoort Wageningen University \& Research wereldwijd tot de aansprekende kennisinstellingen binnen haar domein. De integrale benadering van de vraagstukken en de samenwerking tussen verschillende disciplines vormen het hart van de unieke Wageningen aanpak. 